\title{
Nieuw-Roeselare - landscape archaeological and historical geographical research on deserted medieval settlements in the borderlands of Flanders and Zealand
} \author{
Wim De Clercq ${ }^{1}$ \\ ${ }^{1}$ Department of Archaeology, Faculty of Arts and Philosophy, Ghent University, Belgium \\ ${ }^{2}$ Department of Geography, Faculty of Sciences, Ghent University, Belgium. \\ ${ }^{3}$ Department of History, Faculty of Arts and Philosophy, Ghent University, Belgium. \\ $\bowtie$ gerben.verbrugghe@ugent.be
}

Gerben Verbrugghe ${ }^{1 \otimes}$ - Veerle Van Eetvelde ${ }^{2}$ - Steven Vanderputten ${ }^{3}-$

\begin{abstract}
This paper offers an introduction to the renewed landscape archaeological and historical geographical research on the lost village of Nieuw-Roeselare. Despite being the first site to be studied as a Deserted Medieval Settlement in modern-day Flanders, little is known about the village and its relation to the surrounding landscape. Nieuw-Roeselare is presented as a case study on lost and deserted medieval settlements in the context of the research history on the topic in both Flanders and Zealand. Past historical geographical and archaeological research at the site is described and the ongoing and future research is presented along with its potential for landscape studies and planning.
\end{abstract}

Highlights for public administration, management and planning:

- The identification and mapping of lost medieval settlements allows to contribute to the preservation and conservation management of known sites.

- Insight in the structure and remnants of lost medieval settlements offers opportunities for the incorporation of historic landscape elements in future landscape planning.

- Reconsidering known sites with innovative techniques and methodologies contributes to the further understanding of historic settlement landscapes.

\section{Keywords}

Landscape changes, Landscape archaeology, Deserted Medieval Settlements, Flanders

\section{Received:}

07 September 2020

Received in revised form: 16 November 2020

Accepted:

03 December 2020

The paper was originally presented during the thematic session "Settlement desertion and cultural landscape transformations: connections between past and present" at the $5^{\text {th }}$ Landscape Archaeology Conference held in Newcastle and Durham, UK, in 2018. Selected presentations from the session are now published in this volume as thematic papers exploring the contribution of historical geography, landscape archaeology and landscape heritage studies to preservation, management and planning of historical landscapes.

\section{Introduction}

Cultural landscapes have always been the result of dynamic interactions between natural conditions and human actions (Clark et al. 2003: 3; Muir 2003: 384; Kučera \& Kučerová 2012: 171-172; Antrop \& Van Eetvelde 2017: 142). This is certainly the case for the coastal wetlands and polderlands overlapping the Dutch province of Zealand and the Belgian provinces of West and East Flanders. Throughout time, men have tried to tame the influences of the sea in order to protect and eventually cultivate more land. From the $10^{\text {th }}$ and $11^{\text {th }}$ century onwards, dikes were constructed to protect the settled landscapes against the water (Gottschalk 1955; Rottier 1987: 10-17; Dekker 1988: 607-621; Nicholas 1992: 97-101; Tys 1995; Verhulst 1995: 9-102; Henderikx 2012: $91-106)$. However, $14^{\text {th }}$ to $16^{\text {th }}$ century societal changes and military tactics induced neglect and weakening of the dike network. Both major storm surges and military inundations flooded large areas of the region. Not only did this result in the loss and abandonment of settlements and villages, $17^{\text {th }}$ century re-embankments and infrastructural reorganisations also covered and reshaped the original medieval landscapes of the region (Buisman 1995, 1996; Vanslembrouck et al. 2005; Lehouck et al. 


\section{Sciendo}

2007). The modern-day polder landscape therefore does not easily reveal its history. Nevertheless, around 117 villages in Zealand are known to have been deserted, most of them being lost to the sea (Fig. 1) (Van Strydonck \& De Mulder 2000: 108; Kuipers 2002: 4-5; Adriaanse et al. 2005, 2009). This in stark contrast to the Flemish side of the border, where archaeological and historical research on lost and deserted medieval villages is relatively scarce (Pieters et al. 2008).

The last decade, however, brought a change. Significant multi-disciplinary methodological improvements have been taking place in landscape archaeology, which allow to study buried landscapes of the past through a wide array of non-invasive remote sensing and prospection techniques (Trachet et al. 2017a; Trachet 2018; De Clercq et al. 2018: 81-92; De Ruijsscher 2019: 32-43). This renewed methodological impulse offered opportuni- ties to revisit the site of a lost ${ }^{1}$ medieval village, NieuwRoeselare (New-Roeselare) (Fig. 2). The aim of this paper is to frame the ongoing multidisciplinary research on this lost medieval village within its historical context and evolving landscape archaeological and historical geographical study of deserted and lost medieval villages in Flanders and Zealand.

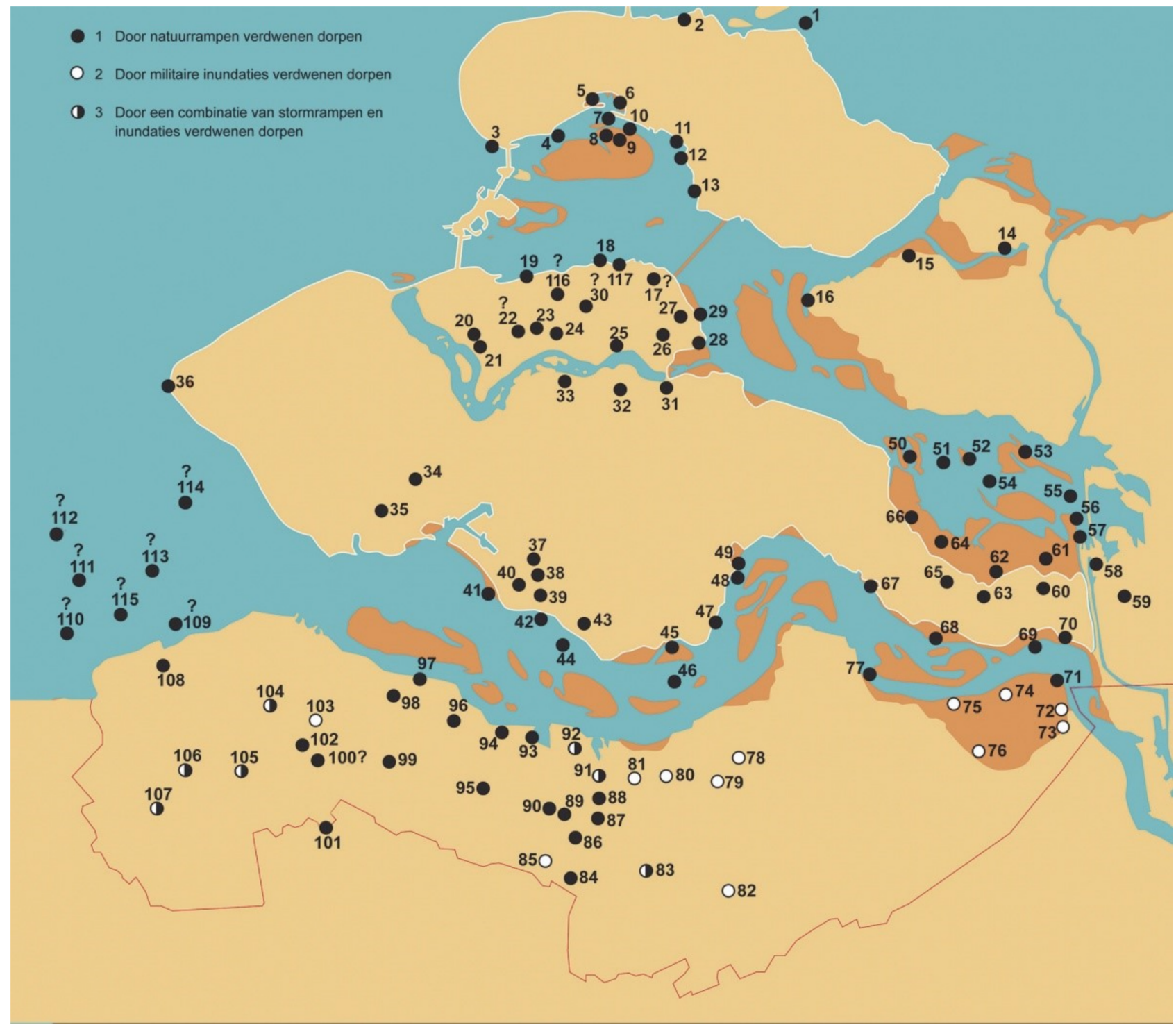

Fig. 1 Overview map of 117 known lost villages and towns in Zealand. 1: Lost due to natural hazards; 2: Lost due to military inundations; 3: Lost due to a combination of storm surges and inundations. Dark orange: known inundated areas (Adriaanse et al. 2009: 4-5) 


\section{sciendo}

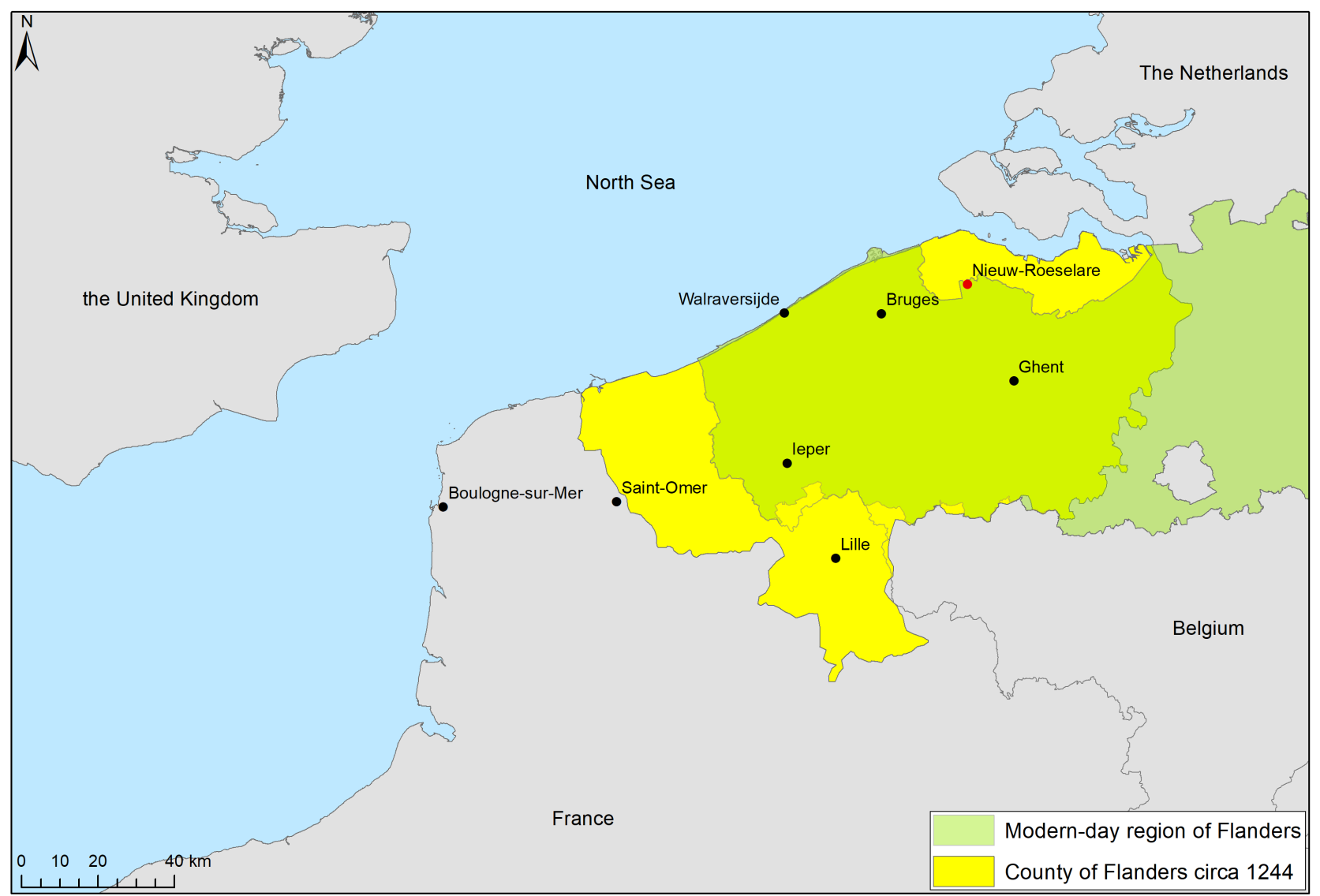

Fig. 2 Location of Nieuw-Roeselare and Walraversijde in relation to major cities in the county of Flanders circa 1244 (Historic boundaries County of Flanders based on Diplomata Belgica-GIS, @ UGent Commission royale d'histoire/Koninklijke Commissie voor Geschiedenis - www.diplomata-belgica.be).

\section{Diversity in research on lost villages, a case of Zeeland versus Flanders}

\subsection{Historic interest for lost villages in Zeeland}

Although both Flanders and Zealand were once part of the medieval County of Flanders, the research history and perceived importance of lost and deserted medieval villages in these two respective regions is strongly differentiated, mainly influenced by differences in accessibility and visibility related to modern-day land use.

In Zealand, already shortly after the $17^{\text {th }}$ century, interest for the lost villages started to develop. The first written records of the finding of remnants date back to 1788 . These describe the experiences of Jacobus Ermerins when he visited the drowned remnants of Reimerswaal in 1776. Once a flourishing harbour town, its structures were still visible on the mudflats along the Oosterschelde river in Zuid-Beveland (Goldschmitz-Wielinga et al. 1995: 3-4; Van Dierendonck \& Kuipers 2004: 61-64). During that $18^{\text {th }}$ century, multiple legends regarding the fall of villages and cities originated. These often had a didactic aspect about humbleness and respect, as did the writings of local historians from the early twentieth century on the subject (Sinninghe \& Sinninghe 1933; Van Dierendonck \& Kuipers 2004: 61-64).

Maria Gottschalks 1955 doctoral thesis on the historical geography of the southern part of Zealand, Zealandic Flanders, brought the first scientific approach into the historical research. The archaeological aspect, however, long remained limited to sporadic descriptions of finds and amateur fieldwork. The $\mathrm{NJBG}^{2}$, for example, surveyed the site of Reimerswaal during their 1971 and 1972 summer camps (Van Dierendonck \& Kuipers 2004: 64-66). The first scientific archaeological research dates back to the 1990s at the site of Valkenisse. The town had been lost to the sea in 1682 , but at the end of the $20^{\text {th }}$ century, some of its structures reappeared from the mudflats due to erosion. This allowed a first topographical survey in 1994, which was followed by consecutive campaigns at the site. This way, large parts of the site were mapped and excavated (Goldschmitz et al. 1995; Kuipers 2002: 1).

Despite centuries of amateur and early scientific research, only in 2000 a first overview map of all known lost villages in Zealand was published. It showed which vil- 
lages and cities were abandoned or lost because of natural hazards, military inundations or both. Two years later, in 2002, a tentative list of the settlements was added, which also indicated the year of the respective abandonments. More than just being an overview map, the document was created as a base for future research (Van Strydonck \& De Mulder 2000: 108; Kuipers 2002: 4-5; Adriaanse et al. 2005, 2009).

\subsection{Nieuw-Roeselare, the 'first' Deserted Medieval Village of Flanders}

On the $25^{\text {th }}$ of November 1965, at a colloquium on the archaeology of the medieval village that was organised by the 'Belgian Center for Rural History', Adriaan Verhulst expressed his concern about the minimal research on deserted medieval villages in Belgium in comparison to its neighbouring countries. Inspired by the work of the Deserted Medieval Village Research Group, a first list of deserted medieval villages was compiled by the Seminar for Economic and Social History of Ghent University. Immediately it was stated that the occurrence of deserted medieval villages in Belgium seemed far more limited than in the surrounding countries. Moreover, there were also considerably less known sites in Flanders compared to available examples in the Walloon region. Extensive historical geographical research by Maria Gottschalk across the border in Zealand, however, had located several lost and deserted villages in northern Flanders as well (Gottschalk 1955; Verhulst 1967: 123-125).

In order to gain more insight into the phenomenon of deserted medieval villages, the Seminar for Archaeology at Ghent University decided in 1967 to start an excavation campaign at one of these sites, the lost village of NieuwRoeselare. It thus became the first Deserted Medieval Village in Flanders to be studied both through historical geography and archaeology. Unfortunately, because of the lack of sufficient funding, the initial goal of the campaign to locate and study the whole extent of the village was not achieved (Verhulst 1967: 123-125; Van Doorselaer \& Verhaeghe 1974: 7).

Despite this first initiative and growing interest, research on lost and deserted villages in Flanders remained limited to small scale excavations in deserted or translocated villages over the following years (De Meulemeester \& Termote 1983: 33; Termote 1987; Mertens 1988; Van Bellingen 2004; Pieters et al. 2008). In contrast to the Dutch examples, all these sites were located more inland from the coastline and located beneath active farmland or developing built-up areas. One exception has been the archaeological research on the late medieval fishing village of Walraversijde near Oostende (Fig. 2), for which Dries Tys (1997) studied the settlement transformation using retrogressive reconstruction of the historical landscape. Archaeological remains of a wide chronological spectrum had already been reported along the shoreline since the $19^{\text {th }}$ century. From 1992 to 2005, the Flemish heritage agency excavated on the other side of the modern-day dunes, where medieval and early mod- ern remains were known to be located. Besides a seawall, streets and chapel, 33 houses of the $15^{\text {th }}$ century village were attested, along with ditch systems and peatcutting pits. Following the archaeological research, four buildings were reconstructed on site to be incorporated in an archaeological visitor centre (Pieters et al. 2013).

\subsection{Cross-border collaboration and research projects}

In 2002, the Stichting Cultureel Erfgoed Zeeland (SCEZ) started a new research project 'Verdronken dorpen in Zeeland' (Drowned villages in Zealand), aiming to collect all available data on lost village in the region and to explore new data sources and methodologies to allow future archaeological and historical geographical research on the subject. Part of the inventory research was done by researchers at Ghent University within the 'Verdwenen cultuurlandschappen in het grensgebied van Vlaanderen en Nederland' project. This focussed on the medieval landscapes and lost villages in the western part of Zeeuws-Vlaanderen and the adjacent regions of Flanders (Kuipers 2002: 6-8; De Kraker 2004: 106-110; Vanslembrouck et al. 2005; Lehouck 2005; Lehouck et al. 2007: 231-241; Gelorini et al. 2010; Trachet 2011).

\subsection{A new impulse along the Zwin}

Since 2013, the 'Medieval Bruges and its associated ports. A landscape-archaeological approach to the Zwindebate' research project at the Department of Archaeology at Ghent University brought a major methodological change to the research field in the region. Its multidisciplinary landscape archaeological approach offered new means to allow detailed research on lost villages based on high resolution data. The research itself focused on the lost medieval outports of Bruges along the former Zwin tidal inlet (Fig. 3), but its innovative methodology has been adapted in other archaeological studies in the region. Dante De Ruijsscher, for example, applied artefactaccurate fieldwalking in combination with historical geographical research at the site of the lost fishing village of Coxyde in the community of Sluis. A similar methodology of fieldwalking, geophysical prospection and historical geographical data has also been applied in the community of Terneuzen, at the sites of Sint Janscapelle and Aendijcke (Trachet et al. 2015; De Reu et al. 2016; Diependaele et al. 2017; Laan \& Tol 2017; De Clercq et al. 2017; Trachet et al. 2017a, b; Trachet et al. 2018; De Ruijscher 2019).

\section{Nieuw-Roeselare, renewed research on an old case study}

In the framework of this longstanding but limited research history and recent methodological innovations, a renewed multidisciplinary research on the site of NieuwRoeselare is ongoing. The aim is to finish where previ- 


\section{sciendo}

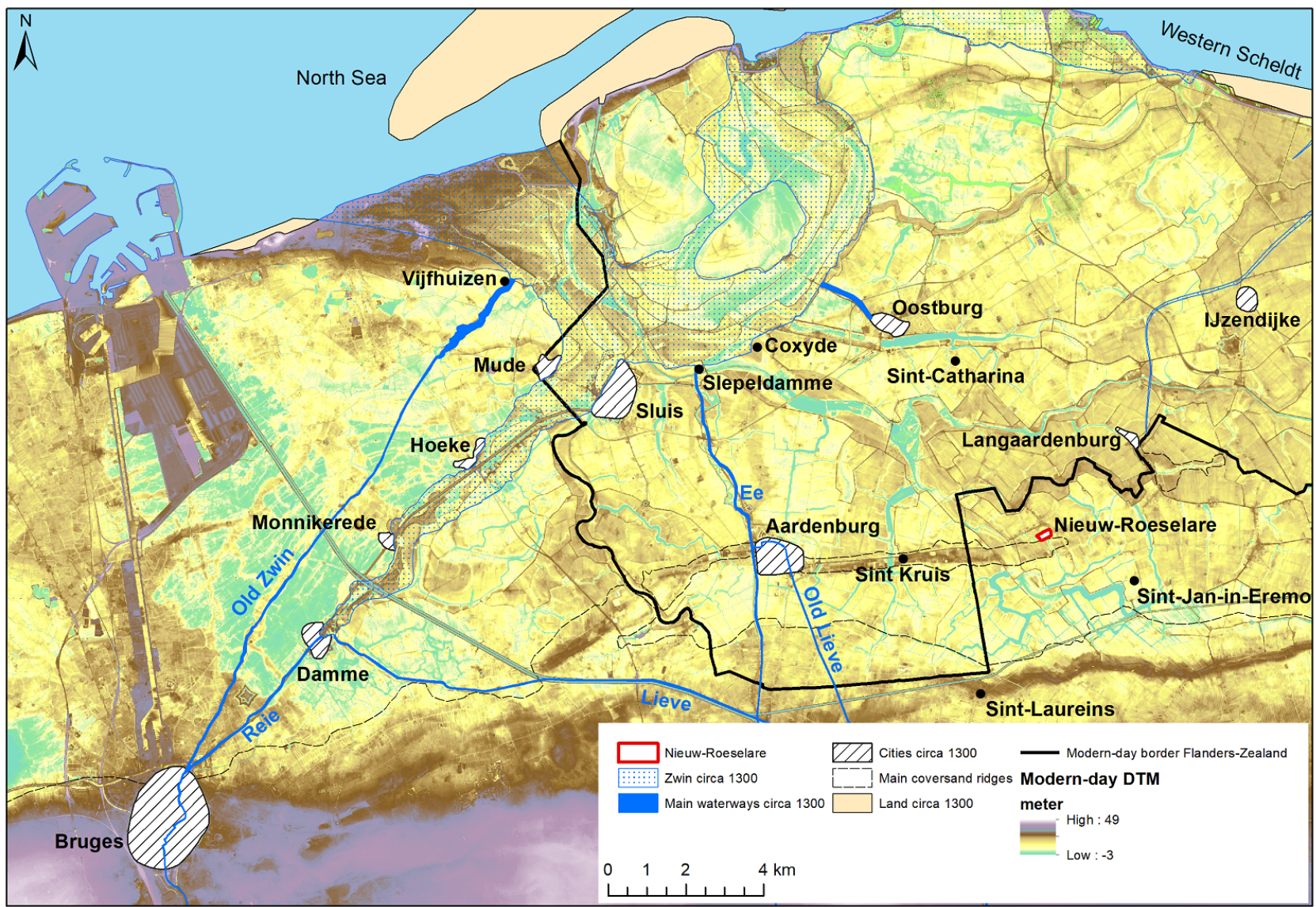

Fig. 3 Map of Nieuw-Roeselare in relation to the historic harbour landscape of Bruges (Trachet \& De Ruijssecher 2019).

ous research struggled, locating the site of the lost village in its whole extent and allowing in depth understanding of its morphology and relation with its surrounding late medieval landscape.

\subsection{Geographical and historical context of Nieuw-Roeselare}

The landscape in northern Flanders is dominated by a series of east-west running coversand ridges and coastal lowlands along the North Sea and the river Scheldt. During the Weichselian, large amounts of fluvial and aeolian sediments were deposited in the central part of an extensive Pleistocene paleovalley. Due to aeolian processes, these sediments were accumulated in east-west oriented ridges among which the Maldegem-Stekene ridge is the largest. It runs over a length of circa $80 \mathrm{~km}$ and is characterised by a microrelief of smaller ridges and depressions. Its gentle northern slope runs into the coastal flats where several smaller coversand ridges have been formed (De Moor \& Heyse 1978; Heyse 1979; Derese et al. 2010: 175; Crombé et al. 2012: 715-716). The lost village of Nieuw-Roeselare is located on the piedmont of one of these smaller ridges, on which also the town of Aardenburg is located (Fig. 3).
The origins of Nieuw-Roeselare date back to July 1241, when Joan countess of Flanders (1206-1244) granted a fief of wastelands, which were depended from the Burg of Bruges, to a citizen of Ghent named Gosuwin de Roeselare (Gottschalk 1955: 66; Van Vooren 1980, II.2.). The first reference to the village, however, is from 1243 . That year, the bishop of Tournai redemarcated several parish boundaries in the region, based on the presence of reclaimed and yet unreclaimed lands. The church of Nieuw-Roeselare was used to delimit the parish boundaries of Saint-Bavo's-Oostburg towards the newly reclaimed lands which ran up to the novam ecclesiam de Rolliers (new church of Roeselare). It is therefore generally assumed that the church was new at the time. (Gottschalk 1955: 64-67; Verstraete 1957; Van Doorselaer \& Verhaeghe 1974: 11) Generally, Gosuwin de Roeselare is considered as the founder of the community with the erection of the church. This is contested by Etienne Van Vooren, who states that the diocese of Tournai had founded the church (Gottschalk 1955: 66-67; Verstraete 1957: 85; Verhulst 1967: 129; Van Doorselaer \& Verhaeghe 1974: 11; Van Vooren 1980, II.2-8.).

The redemarcation of parish boundaries, however, caused multiple tithes disputes with the powerful abbeys in Ghent, Saint-Peter's and Saint-Bavo's. According to Maria Gottschalk, one of these conflicts regarding 


\section{S sciendo}

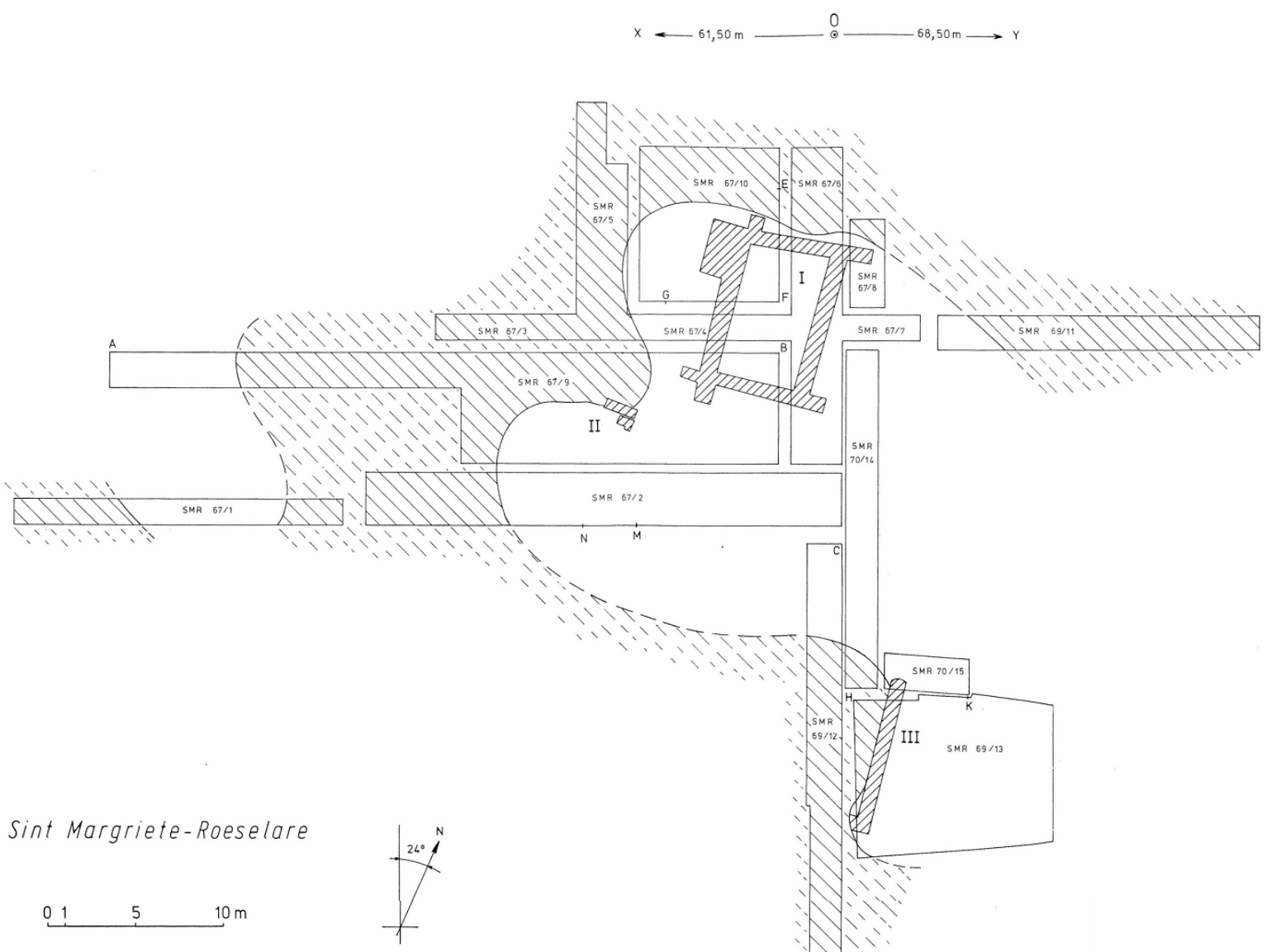

building remains

creeks

Fig. 4 Excavation plan of first archaeological research on the site of Nieuw-Roeselare (van Doorselaer \& Verhaeghe 1974: 16-17).

the lands of Nieuw-Roeselare was settled in 1249. It was decided that the bishop and cathedral chapter of Tournai, together with the hospital at Lille, would collect tithes in que wastina Novum Rollarium appellatur (the wastelands that are called Nieuw-Roeselare) (Gottschalk 1955: 66-67).
Based on the limited historical sources available for Nieuw-Roeselare, its foundation can be related to the so called 'Great Reclamation Period' in the medieval county of Flanders. Internationally, the high medieval period is considered as a period in which people started to make deliberate decisions related to the inten- 


\section{Sciendo}

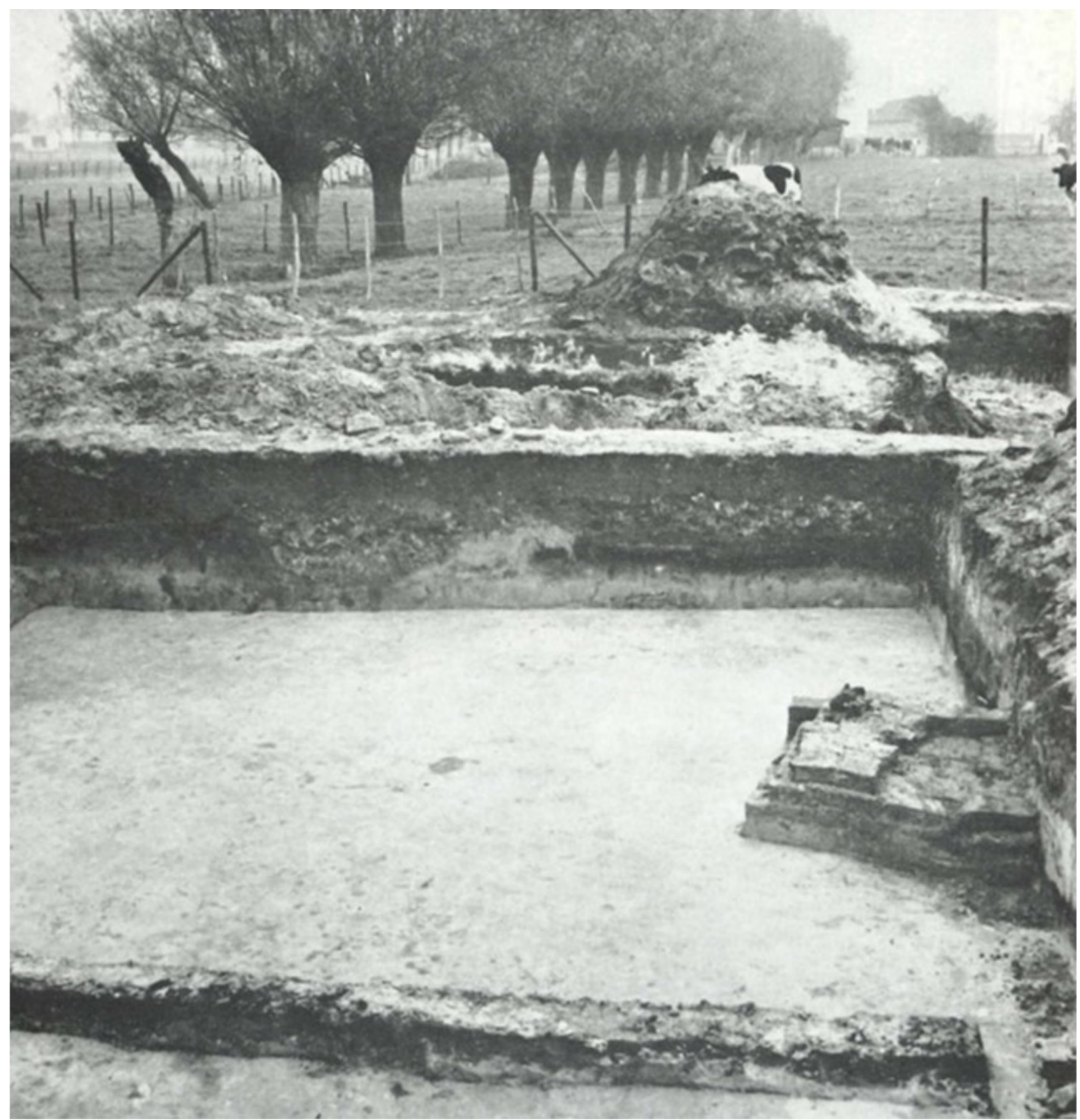

Fig. 5 Original excavation picture showing one of the buttress structures of building I at the assumed manor of Nieuw-Roeselare (section EF (eastern section) of square SMR 67/10), (van Doorselaer \& Verhaeghe 1974: 38).

sification and systematisation of land use and reclamations (Williams 2000). From the $9^{\text {th }}$ century onwards, the County of Flanders had witnessed an increasing urban development and population growth (Nicholas 1992: 107-109; Verhulst 1999: 113-118; Dumolyn et al. 2018a). In order to answer the growing need for more cultivated lands, the $10^{\text {th }}$ to $13^{\text {th }}$ century were characterised by an intensified use and an increasingly systematic exploitation of the landscape ( Verhulst 1965, 1995; Nicholas 1992, 101-107; Thoen 2007; Thoen \& Soens
2015). The latter had been possible thanks to the growing power of the counts of Flanders, who were able to gain control over large areas of (waste)land using a regal right (Verhulst 1965; Tys 1995: 211). Initially reclamations of wastelands and forest clearances focussed on the sandy soils of Inner Flanders (that part of the county outside of the coastal region) (Verhulst 1965, 1995; Thoen 2007: 65-73; Thoen \& Soens 2015). The coastal area would have been used more extensively as terrae ad oves or grazing grounds for large sheep holdings on the marisci 


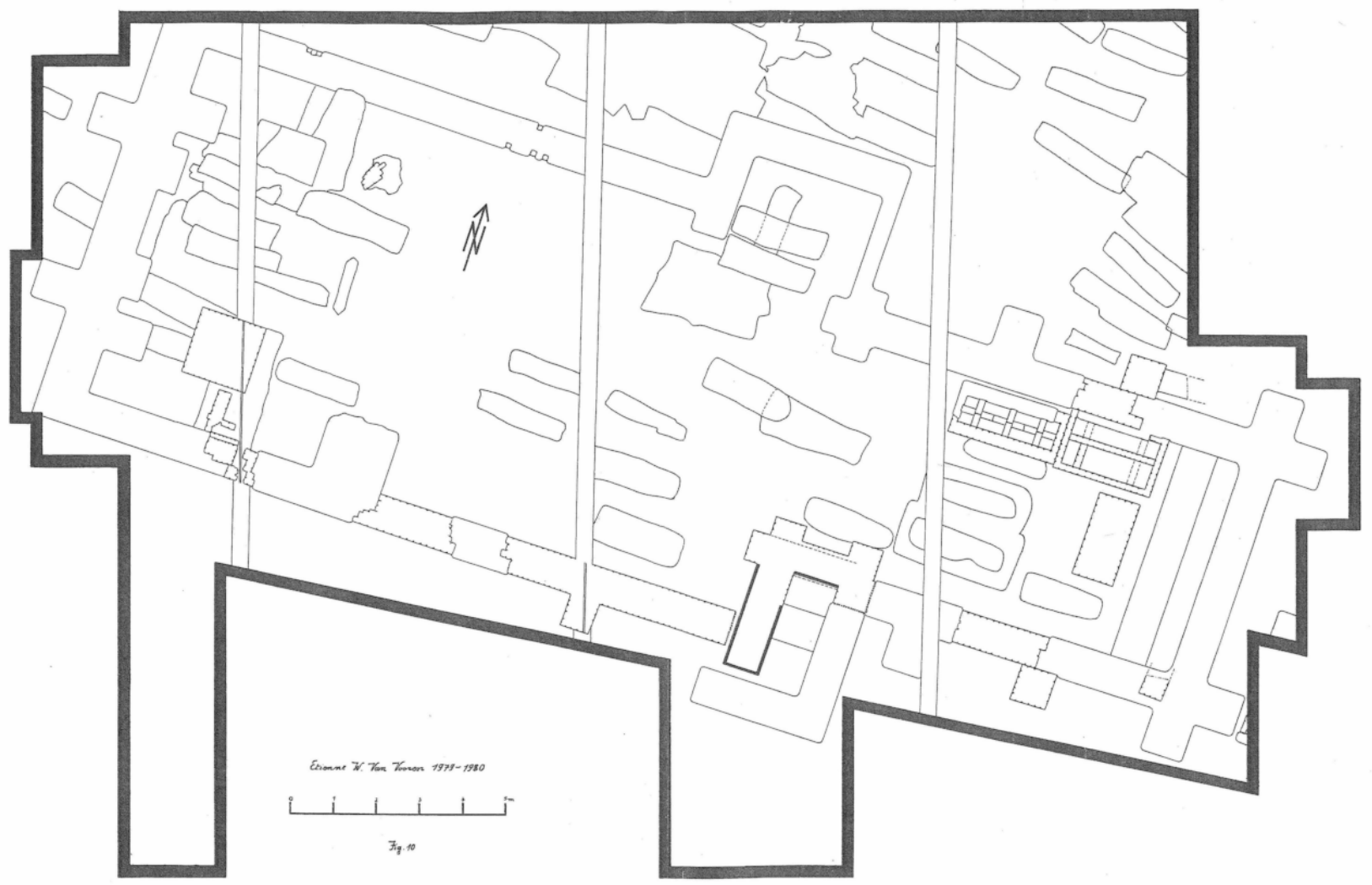

Fig. 6 Excavation plan of the archaeological research on the church of Nieuw-Roeselare in 1979 (van Vooren 1980).

(salt marshes) and individual farms on slightly elevated locations in the tidal landscape (Verhulst 1965: 19; Tys 1995: 207-208). In the context of these sheep holdings on comital lands or domains, though, embankment of the coastal areas started already in the $10^{\text {th }}$ and $11^{\text {th }}$ century using a system of local nuclear embankments or ringdijken as protective enclosures. Subsequently, during the $11^{\text {th }}$ and early $12^{\text {th }}$ century, defensive longitudinal dikes along tidal channels were build. The reclaimed lands were now mainly used as grazing grounds for bercaria and vaccaria or sheep and cow farms which were organised on a large scale (Verhulst 1965: 27; Tys 1995: 217-220). A third stage in the embankment of the coastal region would have been the creation of sea walls parallel with the coast, most likely from the $13^{\text {th }}$ century onwards (Soens et al. 2014: 138). With societal changes and the growing importance of peat as fuel in the mid- $12^{\text {th }}$ and early $13^{\text {th }}$ century, more systematic exploitations started to take place in these coastal regions, eventually influencing the existing dune systems and making the coastal areas more liable to storm surges (Augustyn 1995). In contrast to earlier phases, where the initiative of reclamation often was taken by the Flemish counts and religious institutions, lands were now given in concession or sold to entrepreneurs (Verhulst 1965, 1995; Tys 1995; Thoen 2007: 65-73; Thoen \& Soens 2015: 221-258). Gosuwin de Roeselare would have been one of many knights and lay elites who acquired lands to reclaim this way. In 1249, for example, the parish of Beniardskerke is mentioned for the first time. With its place name meaning 'church of Beniard', it can be assumed that this Beniard was also locally involved in reclamations and erected a church near his residence (De Ruijsscher 2019: 33-34). Indications for the growing importance and exploitation of the region are also given by the founding of other villages in the early $13^{\text {th }}$ century. The church of Sint-Nicolaas-in-Vaerne (Langaardenburg) was first mentioned in 1229. Similar to Gosuwin de Roeselare, Joan countess of Flanders granted a fief of land to the inhabitants of this village in 1235 (Gottschalk 1955: 64-70; De Melker 1988: 97). Earlier, in 1218, she had granted land to the Ter Doest abbey in order for the monks to build housing on slightly higher grounds. Gottschalk locates these lands on the coversand ridge running from Aardenburg towards Nieuw-Roeselare. She interprets this as the possible origin of the village of Sint-Kruis (Gottschalk 1955: 62). Another example is Sint-Catharina near Oostburg, which is first mentioned in 1243 (Gottschalk 1955, 64). The villages of Sint-Laureins and Sint-Jan-in-Eremo are first mentioned in the late $13^{\text {th }}$ century and are most likely related to a consecutive phase of exploitations (Gottschalk 1955: 149). Over the course of the $13^{\text {th }}$ century, the infrastructure in the region was expanded as well. Since the construction of the Ee in 1244 be- 


\section{sciendo}

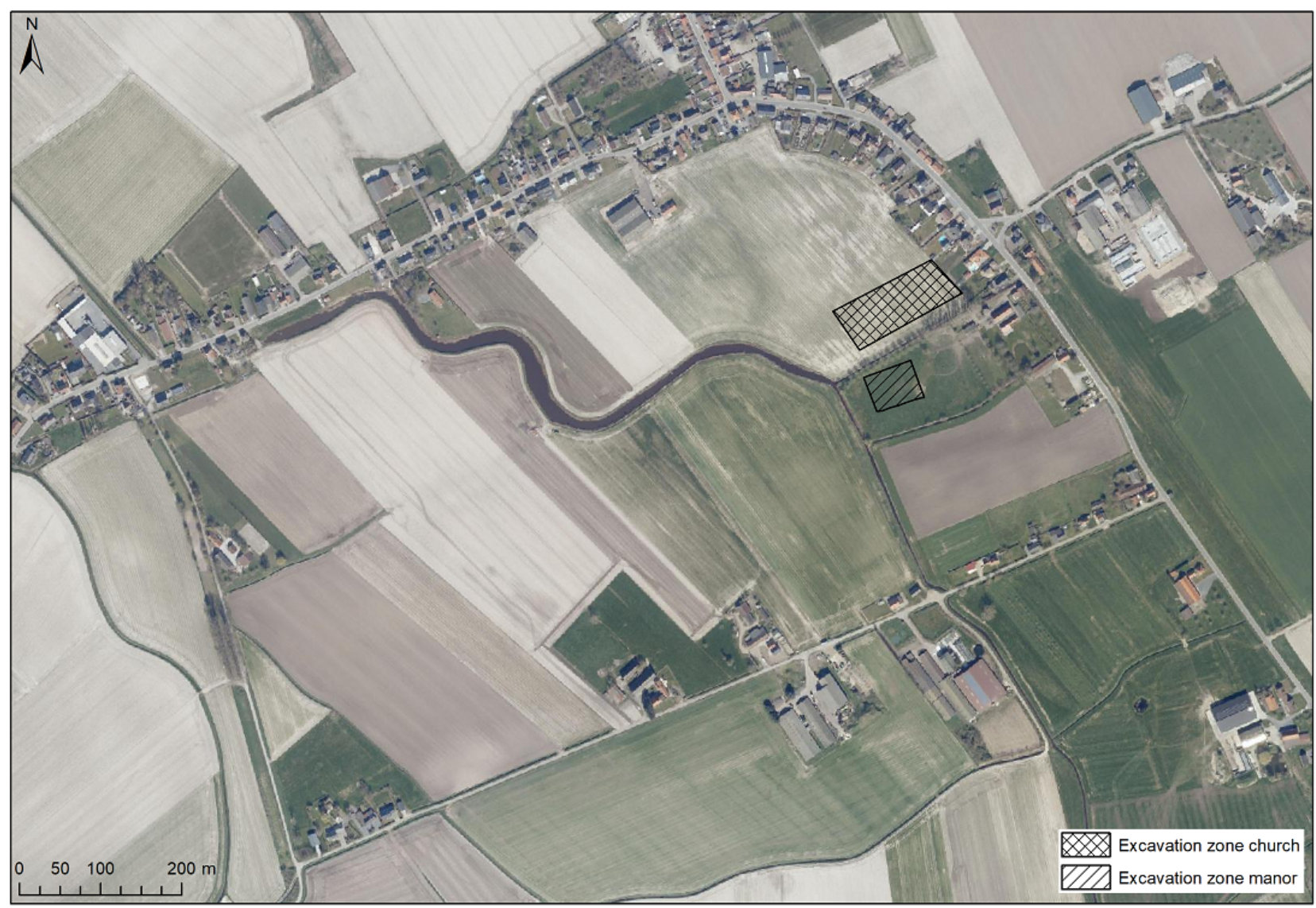

Fig. 7 Location of the first excavations at the site of Nieuw-Roeselare in relation to the modern-day rural context (Orthophoto: orthofotowerkbestand on www.geopunt.be).

tween Aardenburg and the Zwin had created an opportunity for Ghent to make a new connection to the sea, the city had a channel dug in 1251 to Aardenburg. However, this connection failed and in 1262 a new channel, the Lieve, was dug towards Damme instead (Gottschalk 1955: 42-44; De Melker 1988: 103-104).

Regarding Nieuw-Roeselare itself, little is known about its inhabitants and economic importance. In 1309 the village is mentioned as one of the smalle steden (small cities) in the Franc of Bruges. It thus must have been granted city rights, although the reason for its importance is unclear in historical sources (Gottschalk 1955, 68; Verhulst 1967). Local historian Daniël Verstraete suggested a harbour function through a possible connection with the Zwin inlet and the sea via a system of creeks (Verstraete 1957: 87). However, no historical sources are available to support this idea. Westwards, the extensive port system of Bruges developed from the $12^{\text {th }}$ century onwards. Multiple harbour and fishing towns were located along the Zwin inlet as outports of this commercial metropolis. Over the course of the $13^{\text {th }}$ century, Bruges importance in international commerce grew and it became the main commercial hub in the late medieval North Sea area (Trachet et al. 2015; De Clercq et al.
2017; Trachet 2017; Dumolyn et al. 2018b, c). Whether Nieuw-Roeselare as smalle stede in the Franc of Bruges and smaller community in the region had a role in this extensive network is, however, unclear.

Nevertheless, in early October 1375, storm surges along the eastern North Sea coast caused major floods in the eastern part of the county of Flanders. Nieuw-Roeselare was one of the villages that were flooded and had to be abandoned. Despite several attempts to re-embank the lands, the village was never recovered and disappeared beneath fertile farming land (Gottschalk 1955: 162-168; Weikinn 1958: 258; Van Doorselaer \& Verhaeghe 1974: 13; Buisman 1996: 265).

\subsection{First excavation campaigns}

In 1967, the Seminar for Archaeology at Ghent University started an excavation campaign at the site of the lost village of Nieuw-Roeselare. As a first of three campaigns, it is considered as the start of the archaeological research on lost medieval villages in Flanders. Over the course of September $28^{\text {th }}$-November $15^{\text {th }} 1967$, May 28 $8^{\text {th }}$-July $4^{\text {th }} 1969$ and August $14^{\text {th }}-$ September $14^{\text {th }} 1970$, an assumed manor site was excavated by means of long trial 
trenches (Fig. 4 and 7). The remains of three brick constructions were attested by the excavators. Despite clear indications of old "robbery" trenches to extract and reuse building materials, thick walls and buttresses could be attested for the largest of the three building (Fig. 5). Based on the outside buttresses and the presence of cooking pottery and glazed paving tiles in the interior part, the building was interpreted as a substantial dwelling house. However, the inside space only measured 7,90 by 4,60 meters. The remains and materials for the other two buildings were too scanty to determine their extent or make interpretations regarding their function. All finds were dated mid to second half of the fourteenth century, which would correspond to the end phase of habitation at NieuwRoeselare (Van Doorselaer \& Verhaeghe 1974: 16-30).

A fourth archaeological campaign on the site NieuwRoeselare, in 1979, focused on the location of the former church. The fieldwork was executed by the local historical society, 'Heemkundig Genootschap van het Meetjesland', under supervision of Etienne Van Vooren in the context of his master dissertation at the University of Leuven. Two building phases and several inhumations with indications of robbery trenches were attested (Fig. 6 and 7). Initially, a simple rectangular church and straight walled choir would have been build. In a second phase, the east wall of the choir was demolished to allow an extension. The new straight walled choir was strengthened with eight buttresses. Based on this morphology, Van Vooren suggested a late thirteenth to fourteenth century build (Van Vooren 1980).

\section{Concluding remarks and future prospects}

The above described archaeological research, though massively important in its own right for the research field in Flanders, only focussed on parts of the presumed site of Nieuw-Roeselare. Therefore, a new landscape archaeological research project with a multidisciplinary approach was started. The aim of this renewed research is to locate and study the whole extent of the former village and its morphology. The set-up of this renewed research on Nieuw-Roeselare considers a twofold methodological approach in which both desktop- and fieldwork-based research are incorporated. The desktop research aims at collecting, managing, integrating, analysing and visualising all available spatial and non-spatial data in a Geographical Information System (GIS) (Verbrugghe 2019: 60-72). This wide range of source materials comprise historical maps, place names, (historical) aerial photographs and soil data. Subsequently, and based on insights gained from the desktop research, dedicated large scale geophysical surveys applying Electromagnetic Induction (EMI) are executed in order to locate and map the lost settlement of Nieuw-Roeselare (Verbrugghe et al. 2020). On the site level, this must allow to clarify the interaction of the already excavated manor site and church with the yet to be located settlement centre. Moreover on the regional level, a better understanding of NieuwRoeselare in its surrounding physical and socio-economic landscapes is key.

Thanks to the methodological advances of the last decade, it is now possible to build on the results of past research, described in this paper, and add to an elaborated insight in the $13^{\text {th }}$ century reclamations of the coastal borderlands of Flanders and Zealand. This way, insights into the traces and remnants (visible and non-visible) of the lost medieval landscapes will allow to preserve known sites and will contribute to the integration of historic landscape elements in future planning and conservation management. For the site of Nieuw-Roeselare this especially implies the further maintenance of farmers' tracks and creek systems that indicate the location of medieval roads and field systems. Furthermore, preservation of the agricultural land use is key to protect underlying archaeological features.

\section{Footnotes}

1 Although the concept of 'Deserted Medieval Villages' is the most widely phrased in international literature and research, 'deserted' and 'lost' are loosely used in the same context, even in the same publications. The oxford dictionary of archaeology describes Deserted Medieval Villages as "The abandoned remains of a nucleated rural settlement [...] [which] survive as earthworks or, in marginal areas, as ruinous structures". From the early development of the research field in the United Kingdom by researchers such as W. G. Hoskins, Maurice Beresford and John Hurst, this was indeed the case. Based on historical research, depopulation and economic failure caused the abandonment of most of these villages. Subsequent land use preserved its remnants for centuries. In the case of Nieuw-Roeselare, no clear subsurface features were preserved since the village now lies beneath farming land. Therefore, in this paper, the village is referred to as being lost instead of deserted (Beresford 1951: 129-147; Hilton 1968: 104-109; Beresford 1969; Beresford Hurst 1971; Darvill 2008: 129; Christie Stamper 2012; Hoskins 2013: 110-111).

${ }^{2}$ Nederlandse Jeugdbond tot Bestudering van de Geschiedenis (Dutch youth federation for the study of history), a Dutch youth movement with a strong interest in history.

\section{References}

Adriaanse L, Van Dierendonck R, Kuipers J (2005) Verdronken dorpen in Zeeland 2. Zeeuws Erfgoed Special 12.

Adriaanse L, Van Dierendonck R, Kuipers J (2009) Verdronken dorpen in Zeeland 3. Zeeuws Erfgoed Special 14.

Antrop M, Van Eetvelde V (2017) Landscape Perspectives, The Holistic Nature of Landscape. Springer, Dordrecht.

Augustyn B (1995) De evolutie van het duinecosysteem in Vlaanderen in de Middeleeuwen: antropogene factoren versus zeespiegelrijzingstheorie. Historisch-Geografisch Tijdschrift 13(1): 9-19.

Beresford M (1951) The Lost Villages of Medieval England. The Geographical Journal 117(2): 129-147.

Beresford M (1969) The Lost villages of England. Lutterworth Press: London. 


\section{sciendo}

Beresford M, Hurst J (1971) Deserted Medieval Villages. Studies. Lutterworth Press: London.

Buisman J (1995) Duizend jaar weer, wind en water in de Lage Landen, Deel 1: Tot 1300. Van Wijnen: Franeker.

Buisman J (1996) Duizend jaar weer, wind en water in de Lage Landen, Deel 2: 1300-1450. Van Wijnen: Franeker.

Christie N, Stamper P (2012) Medieval Rural Settlement. Britain and Ireland, AD 800-1600. Windgather Press: Exeter.

Clark J, Darlington J, Fairclough G (2003) European Pathways to the Cultural Landscape 2000-2003. EPCL: Heide.

Crombé Ph, Van Strydonck M, Boudin M, Van Den Brande T, Derese C, Vandenberghe D, Van Den Haute P, Court-Picon M, Verniers J, Gelorini V, Bos J, Verbruggen F, Antrop M, Bats M, Bourgeois J, De Reu J, De Maeyer Ph, De Smedt Ph, Finke P, Van Meirvenne M, Zwertvaegher A (2012) Absolute dating (C14 and OSL) of the formation of coversand ridges occupied by prehistoric hunter-gatherers in NW Belgium. Radiocarbon 54 (3-4): 715-726.

Darvill T (2008) The concise Oxford dictionary of Archaeology. Oxford University Press: Oxford.

De Clercq W, Dreesen R, Dumolyn J, Leloup W, Trachet J (2017) Ballasting the Hanse: Baltoscandian erratic cobbles in the Later Medieval port landscape of Bruges. European Journal of Archaeology 20(4): 710-736.

De Clercq W, Trachet J, De Reu J (2018) Artefact-Accurate Fieldwalking in Flanders. Integrating medieval surface finds with geophysical and historical data. In: Wohlfarth C, Keller $C$ (eds) Funde in der Landschaft. Neue Perspektiven und Ergebnisse archäologischer Prospektion. Materialien zur Bodendenkmalpflege im Rheinland 26, LVR-Amtes für Bodendenkmalpflege im Rheinland, Bonn, pp. 81-92.v Dekker C (1988) Tussen twee vloeden, de strijd tegen het water in Zeeland bewesten Schelde tussen 1530 en 1532. Bijdragen en mdedelingen betreffende de geschiedenis der Nederlanden 103(4): 607-621.

De Kraker A (2004) Verdronken dorpen in kaart gebracht. Zeeland 13(3): 106-110.

De Melker B (1988) De ontwikkeling van de stad Aardenburg en haar bestuurlijke instellingen in de Middeleeuwen. CRGGZ, Middelburg.

De Meulemeester J, Termote J (1983) De middeleeuwse dorpskern van Zoutenaaie (Veurne). Onderzoek van een woonsite en van de kerk. Archaeologio Belgica 254: 33.

De Moor G, Heyse I (1978) De morfologische evolutie van de Vlaamse Vallei.De aardrijkskunde 4: 343-375.

De Reu J, Trachet J, Laloo P, De Clercq W (2016) From low cost UAV survey to high resolution topographic data: developing our understanding of a Medieval outport of Bruges. Archaeological Prospection 23(4): 335-346.

Derese C, Vandenberghe D, Zwertvaegher A, Court-Pion M, Crombé Ph, Verniers J, Van den Haute P (2010) The timing of Aeolian events near archaeological settlements around Heidebos (Moervaart area, N Belgium). Netherlands Journal of Geosciences - Geologie en Mijnbouw 89(3): 173-186.

De Ruijsscher D (2019) Verwoest en verdestrueerd. Multidisciplinair onderzoek naar het verdwenen dorp Coxyde. Tijdschrift voor Historische Geografie 4(1): 32-43.v Diependaele S, D'Hondt F, Brijker J, Saey T, Wattenberghe J (2017) Zaamslag Poonhaven. Verdronken dorp Aendijcke, Gemeente Terneuzen. Een inventariserend Veldonderzoek door middle van verkennende boringen, oppervlaktekartering, geofysisch onderzoek en karterende boringen. Artefact! Rapport 280, Zaamslag.
Dumolyn J, Declercq G, Meijns B, Hillewaert B, Hollevoet Y, Ryckaert M, De Clercq W (2018a) Origins and Early History. In: Brown A, Dumolyn J (eds) Medieval Bruges c. 850-1550. Cambridge University Press, Cambridge, pp. 7-51.

Dumolyn J, Ryckaert M, Meijns B, Deneweth H, Devliegher L (2018b) The Urban Landscape I: c. 1100-c.1275. In: Brown A, Dumolyn J (eds) Medieval Bruges c. 850-1550. Cambridge University Press, Cambridge, pp. 52-85.

Dumolyn J, Ryckaert M, Deneweth H, Devliegher L, Dupont G (2018c) The Urban Landscape II: c.1275-c.1500. In: Brown A, Dumolyn J (eds) Medieval Bruges c. 850-1550. Cambridge University Press, Cambridge, pp. 152-195.

Gelorini V, Lehouck A, Vanslembrouck N, Mulder J, Thoen E, Vervloet J (2010) Interdisciplinair onderzoek naar verdwenen cultuurlandschappen in het grensgebied van Vlaanderen en Nederland: problemen, nieuwe mogelijkheden en toepassingen. VOBOV-INFO 64: 2-19.

Goldschmitz-Wielinga L, Van Heeringen R, Hendrikse H, Kuipers J, van der Linden D, Smits J (1995) Verdronken land, Valkenisse en Keizershoofd. Archeologisch en historisch onderzoek van een verdronken stukje Zuid-Beveland. De Koperen Tuin, Goes.

Gottschalk M. (1955) Historische Geografie van Westelijke Zeeuws-Vlaanderen tot de St-Elisabethsvloed van 1404. Van Gorcum \& Comp.: Assen.v Henderikx P (2012) Landschap, bewoning, sociale structuren. In: Brusse P, Henderikx P (eds) Geschiedenis van Zeeland, Deel 1: Prehistorie - 1550. W Books, Zwolle, pp. 91-106.

Heyse I (1979) Bijdrage tot de geomorfologische kennis van het noordwesten van Oost-Vlaanderen. Brussel.

Hilton R. (1968) Villages désertés et histoire économique: recherches françaises et anglaises. Etudes Rurales 32: 104-109.

Hoskins W (2013, 3d edition) The making of the English landscape. Little Toller Books: Lower Dairy.

Kucera Z, Kucerova S (2012) Historical geography of persistence, destruction and creation: the case of rural landscape transformations in Czechia's resettled borderland. Historická Geografie 38(1): 165-184.

Kuipers J (2002) Verdronken dorpen in Zeeland. Zeeuws Erfgoed Special 3.

Laan W, Tol A (2017) Vindplaats Zandstraat-Sint Jandscapelle, gemeente Terneuzen. Een inventariserend veldonderzoek middels verkennend en waarderen booronderzoek, geofysisch onderzoek en een veldkartering. Archol Rapport 372, Leiden.

Lehouck A (2005) Het verzwolgen cultuurlandschap. Archeologische sporen van middeleeuwse infrastructuur in westelijk Zeeuws-Vlaanderen. Tijdschrift voor Waterstaatsgeschiedenis 14: 59-78.v Lehouck A, Vanslembrouck N, Gelorini V, Soens T, Thoen E, Vervloet J (2007) Reconstructing disappeared landscapes of wet areas: Western Sealand Flanders. In: Roca Z, Spek T, Terkenli T, Plieninger T, Höchtl F (eds.) Euroepan Landscapes and Lifestyles, the Mediterranean and Beyond. Edições universitárias Lusófonas, Lisbon, 231-241.

Mertens J (1988) De verdwenen kerk van Roksem. In: Berings G, Hoste A, Meulemeester J, Vangheluwe R, Van Der Bauwhede D, Van Der Perre J (eds) Kerkschatten uit Oudenburg. Gemeente Oudenburg, Oudenburg, pp. 45-56.

Muir R (2003) On change in the landscape. Landscape Research 28(4): 383-403.

Nicholas D (1992) Medieval Flanders. Longman, London. 


\section{sciendo}

Pieters M, Dewilde M, Ameels V (2008) Verlaten dorpen. Onderzoeksbalans Archeologie Agentschap Onroerend Erfgoed. Available at: <https://onderzoeksbalans.onroerenderfgoed.be/onderzoeksbalans/archeologie/late middeleeuwen en moderne tijden/landelijke_archeologie/verlaten_dorpen>

Pieters M, Baeteman C, Bastiaens J, Bollen A, Clogg Ph, Cooremans B, De Bie M, De Buyser F, Decorte G, Deforce K, De Groote A, Demerre I, Demiddele H, Ervynck A, Gevaert G, Goddeeris T, Lentacker A, Schietecatte L, Vandenbruaene M, Van Neer W, Van Strydonck M, Verhaeghe F, Vince A, Watzeels S, Zeebroek I (2013) Het archeologisch onderzoek in Raversijde (Oostende) in de periode 1999-2005. Vuurstenen artefacten, een Romeinse dijk, een 14de-eeuws muntdepot, een 15 de-eeuwse sector van een vissersnederzettingen en sporen van een vroeg-17de-eeuwse en een vroeg-18de-eeuwse belegering van Oostende. Relicate Monografieën 8. Onroerend Erfgoed, Brussel.

Rottier H. (1987) Het Verdronken Land van Saeftinghe. Spiegel Historiael 22(1): 10-17.

Sinninghe J, Sinninghe M (1933) Zeeuwsch Sagenboek. Thieme, Zutphen.

Soens T, Tys D, Thoen E (2014) Landscape transformation and social change in the North Sea polders, the example of Flanders (1000-1800 AD). Sielungsforschung, Archeologie-GeschichteGeographie 31: 133-160.

Termote J (1987) De verdwenen dorpskern van 's Heerwillemskapelle (Veurne). Archaeologia Mediaevalis 10: 69-70.

Thoen E (2007) Het landschap in de Middeleeuwen en de Modern Tijdens. In: Prevenier W, Van Eenoo R, Thoen E (eds) Geschiedenis van Deinze, Deel 3: Het platteland en de dorpen in Deinze. Stad Deinze, Deinze, pp. 65-73.

Thoen E, Soens T (2015) The Low Countries, 1000-1750. In Thoen E, Soens T (eds) Struggling with the environment: land use and productivity. Brepols, Turnhout, pp. 221-258.

Trachet J (2011) Verdronken dorpen in het zuidoosten van Zeeland. Nieuw bronmateriaal opent nieuwe perspectieven. Symposium Onderzoek Jonge Archeologen, pp. 21-31.

Trachet J, Delefortrie S, Dombrecht K, Dumolyn J, Leloup W, Thoen E, Van Meirvenne M, De Clercq W (2015) Turning back the tide: the Zwin debate in perspective. A historiographical review of the medieval port system northeast of Bruges. Revue du Nord 97 (413): 305-321.

Trachet J, De Ruijsscher D, (2019) Medieval Bruges and its outports. A landscape-archaeological contribution to the Zwin-debate, in: European Harbour Data Respository. doi.org/10.22032/dbt.38396

Trachet J (2017) Verlande voorhavens, verdwenen middeleeuwse havensites in de Zwinstreek. Monumenten en Landschappen 5 : 6-25.

Trachet J, Delefortrie S, Van Meirvenne M, Hillewaert B, De Clercq W (2017a) Reassessing surface Artefact Scatters. The integration of Artefact-Accurate Fieldwalking with Geophyscial Data at Medieval Harbour Site near Bruges (Belgium). Archaeological Prospection 24(2): 101-117.

Trachet J, Poulain M, Delefortrie S, Van Meirvenne M, De Clercq W (2017b) Making a mountain out of a molehill?: a low-cost and time-efficient molehill survey of the lost medieval harbour site of Monnikerede, Belgium. Journal of field archaeology 42(6): 503-513.

Trachet J (2018) Mapping/painting the Medieval landscape. A landscape-archaeological analysis of the medieval landscape as depicted by Pieter Pourbus. E-Perimetron 13(2): 112-120.
Trachet J, Leloup W, Delefortrie S, Dumoly, J, Thoen E, Van Meirvenne M, De Clercq W (2018) Moddeling Monnikerede: the topographical reconstruction of a deserted medieval outport near Bruges. Medieval Low Countries: 91-130.

Tys D. (1995) The Medieval Embankment of Coastal Flanders in Context. In: Thoen E, Borger G, De Kraker A, Soens T, Tys D, Vervaet L, Weerts H (eds) Landscapes or Seascapes. Brepols, Turnhout, pp. 199-239.

Tys D (1997) Landscape and Settlement: the Development of a Medieval Village along the Flemish Coast. In: De Boe G, Verhaeghe F (eds) Rural settlements in medieval Europe. IAP, Zellik, pp. 157-167.

Van Bellingen S (2004) De verdwenen Sint-Gorikskerk te Kobbegem (gem. Asse, Vl.-Br.). Archaeologia Mediaevalis 27: 30-31.

Van Dierendonck R, Kuipers J (2004) Omgaan met verdronken dorpen. In: Kuipers J (ed.) Sluimerend in slik. Den Boer - De Ruiter, Middelburg, 61-64.

Van Doorselaer A, Verhaeghe F (1974) Excavations at the XIVth century village of Roeselare (Sint-Margriete). De Tempel, Brugge.

Vanslembrouck N, Lehouck A, Thoen E (2005) Past landscapes and present-day techniques: reconstructing submerged medieval landscapes in the western part of Sealand Flanders. Landscape History 27(1): 51-64.

Van Strydonck M, De Mulder G (2000) De Schelde, Verhaal van een rivier. Davidsfonds: Leuven.

Van Vooren E (1980) De kerk van Nieuw-Roeselare. Een Archeologische benadering in historisch-topografisch perspectief. KU Leuven, Leuven.

Verbrugghe G (2019) Novum Rollarium: an introductory case study on planted grouped settlements in the context of high medieval landscape reclamations in the county of Flanders and beyond. Medieval Settlement Research 34: 60-72.

Verbrugghe G, Saey T, De Clercq W (2020) Lost but revived: revisiting the medieval village of Nieuw-Roeselare (Flanders) using large scale frequency-domain multi-receiver EMI and landscape archaeological prospection. Archaeological Prospection 27(3): 239-252.

Verhulst A (1965) Het landschap in Vlaanderen in Historisch Perspectief. De Nederlandsche Boekhandel, Antwerpen.

Verhulst A (1967) Note pour server à l'étude archéologique de villages désertés en Belgique. In: Genicot L, Verhulst A (eds.) L'archéologie du village medieval. Belgisch centrum voor landelijke geschiedenis, Leuven and Gent, pp. 123-132.

Verhulst A (1995) Landschap en Landbouw in Middeleeuws Vlaanderen. Gemeentekrediet: Brussel.

Verhulst A (1999) The Rise of Cities in North-West Europe. Cambridge University Press: Cambridge.

Verstraete D (1957) Geteisterde dorpen in het noorden van het Meetjeslan. Appeltjes van het Meetjesland 8: 77-108.

Weikinn C (1958) Quellentexte zur Witterungsgeschichte Europas von der Zeitwende bis zum Jahre 1850, Hydrographie Teil 1 (Zeitwende - 1500). Akademie Verlag: Berlin.

Williams M (2000) Dark ages and dark areas: global deforestation in the deep past. Journal of Historical Geography 26 (1): 28-46. 